\title{
SOCIAL MAPPING UNTUK MENGANTISIPASI POTENSI KONFLIK DI PERTAMBANGAN BATUBARA KABUPATEN KUTAI BARAT, KALTIM
}

\author{
Margana Wiratma \\ Jurusan Marketing Communication, Fakultas Komunikasi dan Multimedia, \\ Bina Nusantara University, Jln. K.H. Syahdan No 9, Palmerah, Jakarta Barat 11480 \\ margana@binus.ac.id
}

\begin{abstract}
This article tries to map the social condition by classifying the CSR (corporate social responsibility) main theories. The purpose of this social mapping is to identify the predefined indicators related to sociopolitical and cultural conditions. This method concentrates on a relative ranking of people's socio-political and cultural conditions, rather than making an absolute assessment. The object of social mapping survey is the stakeholers and people related to the business activities of the coal mining corporates in the regent of Kutai Barat, Kalimantan Timur. By identifying the socio-political and cultural aspects, the corporate can anticipate and avoid any social conflicts about their business. The social mapping on socio-political and cultural aspect is very important for any coal mining corporates before launching their business on exploring as well as on exploiting by the CSR program. The CSR field presents not only a landscape of theories, but also a proliferation of approaches, which are controversial, complex and unclear. The social mapping on socio-political and cultural aspects is usefull for any coal mining companies at Kutai Barat in implementing the CSR. The CSR theory, in practice, presents four dimensions related to profit, political performance, social demands, and ethical values.
\end{abstract}

Keywords: social mapping, corporate social responsibility, social conflict, coal mining corporate

\begin{abstract}
ABSTRAK
Artikel ini mencoba untuk memetakan kondisi sosial dengan mengelompokkan teori-teori utama CSR (tanggung jawab sosial perusahaan). Tujuan dari pemetaan sosial adalah untuk mengidentifikasi indikator standar terkait dengan kondisi sosial-politik dan budaya. Metode ini berkonsentrasi pada peringkat relatif dari kondisi sosio-politik dan budaya, tanpa membuat penilaian mutlak. Objek survei pemetaan sosial adalah stakeholders dan orang-orang yang terkait dengan kegiatan usaha korporasi pertambangan batubara di Kabupaten Kutai Barat, Kalimantan Timur. Dengan mengidentifikasi aspek sosial-politik dan budaya, perusahaan dapat mengantisipasi dan menghindari konflik sosial tentang bisnis mereka. Pemetaan sosial terhadap aspek sosial-politik dan budaya sangat penting bagi setiap korporasi pertambangan batubara sebelum meluncurkan bisnis mereka pada eksplorasi serta pada pemanfaatan oleh program CSR. Bidang CSR tidak hanya menyajikan pemandangan teori, tetapi juga proliferasi pendekatan, yang kontroversial, kompleks dan tidak jelas. Pemetaan sosial pada aspek-aspek sosial-politik dan budaya sangat berguna untuk setiap perusahaan pertambangan batubara di Kutai Barat dalam pelaksanaan CSR. Teori CSR, dalam praktiknya, menyajikan empat dimensi yang berhubungan dengan keuntungan, kinerja politik, tuntutan sosial, dan nilainilai etika.
\end{abstract}

Kata kunci: social mapping, corporate social responsibility, social conflict, coal mining corporate 


\section{PENDAHULUAN}

Untuk melakukan suatu kegiatan usaha pertambangan batubara, perusahaan pertambangan yang mengelolanya dituntut untuk memahami peta sosial politik dan sosial kebudayaan dari masyarakat di area pertambangan maupun sekitarnya. Masalahnya, kegiatan pertambangan batubara akan berdampak langsung kepada masyarakat, dan melibatkan kepentingan masyarakat di areal maupun di sekitarnya. Dengan mengetahui secara pasti kondisi sosial politik dan kebudayaan dari masyarakat di areal maupun di sekitar pertambangan, perusahaan itu akan lebih tepat menentukan langkah-langkah operasional dalam melakukan penambangan dan penggalian batubara. Mereka yang memiliki akses dengan masyarakat di lokasi atau sekitarnya, berpotensi untuk mendukung proses eksplorasi dan eksploitasi pertambangan batubara itu. Sebaliknya apabila perusahaan pertambangan tidak menangani dengan baik, mereka bisa saja mendatangkan gangguan sosial, yang akan berdampak kepada proses penambangan maupun kegiatan usaha pertambangan itu.

Karena itu, perusahaan pertambangan diharapkan memiliki peta sosial politik dan kebudayaan sebelum memulai kegiatan usaha pertambangan. Salah satu metode yang sering digunakan untuk mendapatkan peta tersebut adalah dengan penelitian pemetaan sosial atau survei social mapping. Pemetaan sosial adalah suatu penelitian di lapangan yang dimaksudkan untuk memperoleh gambaran lebih jelas peta sosial politik, keamanan dan kebudayaan di suatu kawasan. Bahkan, pemetaan sosial bisa difokuskan untuk kepentingan tertentu, seperti kegiatan pertambangan batubara. Adapun wilayah yang akan menjadi obyek penelitian adalah Kabupaten Kutai Barat, Kalimantan Timur. Kutai Barat dipandang penting karena diperkirakan memiliki kandungan batubara cukup besar. Sementara perusahaan yang sudah beroperasi baru dua perusahaan yakni PT Gunung Bayan Pratama dan PT Trubaindo Coal Mining. Selain itu, Kutai Barat merupakan kabupaten yang memiliki kebudayaan khas karena pengaruh suku Dayak Benuaq yang mendominasi populasi di wilayah itu. Karakteristik suku Dayak Benuaq memiliki pengaruh yang cukup besar bagi jalan pikiran dan gaya kepemimpinan pemerintahan di lingkungan Kabupaten Kutai Barat dan kecamatan-kecamatannya. Selain itu, budaya Dayak Benuaq juga memiliki pengaruh cukup besar bagi sikap, tingkah laku, dan jalan pikiran dari masyarakat Kutai Barat.

Pemetaan sosial, selain penting untuk jalannya kegiatan usaha pertambangan di Kutai Barat, juga diperlukan oleh perusahaan untuk menentukan langkah bagaimana melakukan pendekatan dengan masyarakat di areal pertambangan maupun di sekitarnya. Peta sosial politik dan sosial kebudayaan tersebut dalam dunia bisnis berkaitan erat dengan upaya perusahaan atau kegiatan usaha dalam menghadapi dan menyapa masyarakat sekitarnya. Dalam dunia usaha, hal tersebut sering dikaitkan dengan corporate social responsibility (CSR). Pemikiran CSR yang berkembang sampai sekarang ini pada mulanya berasal dari pemikiran yang diluncurkan oleh Howard R. Bowen awal 1950-an, yang berargumentasi bahwa para eksekutif perusahaan harus memiliki tanggungjawab dalam melakukan kegiatan usaha dengan senantiasa memperhatikan sasaran dan nilai-nilai yang hidup dari masyarakat (Bowen, 1953).

Pada awal tahun 1960-an, aspek moral atau etika dari kegiatan usaha (bisnis) mulai menonjol ke permukaan. Pada kenyataan ketika itu, kalangan bisnis dianggap telah menjual produk yang tidak aman untuk masyarakat, mengakibatkan polusi ke lingkungannya, main suap dalam praktek bisnis internasional. Moralitas seolah sudah digantikan oleh upaya mengejar untung dan kekuasaan (Spencer \& Butler, 1987). Perusahaan dicitrakan sebagai yang jahat dan konsumen selalu memrotes kelakuan bisnis mereka yang tidak bermoral. Sebagai reaksi terhadap hal tersebut, ada keinginan yang menguat untuk melakukan kegiatan sosial yang menguntungkan. Diskusi itu terjadi baik di kalangan para eksekutif perusahaan maupun kalangan akademisi di kelas. Gagasan yang mengkristal adalah bahwa bisnis jangan sampai hanya memburu untung dan uang, tapi juga harus memperhatikan moralitas. Maka, sejak 1970-an, keinginan untuk memberikan kontribusi sosial tersebut menigkat, dan fokusnya 
bukan hanya pada sektor produksi dari suatu perusahaan. Perusahaan juga harus memperhatikan untuk membuat kesejahteraan para pekerjanya, pelanggan, stakeholders yang lain, dan juga pihak luar perusahaan dan lingkungan hidup di sekitarnya (Lantos, 2001 seperti dikutip Emile Helmer dan Karin Stahl dalam How to define Corporate Social Responsibility. 2009).

Bidang cakupan CSR bukan hanya menampilkan tataran teori, tapi juga berbagai pendekatan yang menggebu-gebu yang sering mengundang kontroversi, kompleks, dan tidak jelas. Ada 4 (empat) kelompok utama dari teori CSR: (1) Instrumental theories: dimana perusahaan kelihatannya hanya sebagai sebuah alat untuk menciptakan kesejahteraan. Kegiatan sosialnya hanya meruapakan alat untuk mencapai keuntungan ekonominya dari perusahaan itu sendiri; (2) Political theories: dimana perusahaan peduli dengan kekuatan dari perusahaannya di tengah-tengah masyarakat. Perusahaan menggunakan tanggungjawab sosialnya sebagai kekuatan dalam arena politik; (3) Integrative theories: dimana perusahaan memfokuskan diri pada upaya untuk senantiasa memuaskan tuntutan masyarakat; dan (4) Ethical theories: yang didasarkan pada tanggungjawab moral baik dari perusahaan maupun masyarakat. Dalam prakteknya, setiap teori CSR senantiasa menampilkan pula keempat dimensi yang berkaitan dengan keuntungan, kekuatan politik, tuntutan masyarakat, dan nilai moral. Berbagai penemuan CSR mendukung perlunya mengembangkan teori baru, baik untuk kegiatan usaha maupun hubungan sosial yang harus memadukan keempat teori tersebut (Gariga, Elisabeth \& Mele, Domenec). Karena CSR baik secara teori maupun praktek sangat penting bagi perusahaan pertambangan batubara, maka mereka harus melakukan pemetaan sosial agar bisa melakukan CSR tersebut tepat sasaran. Perusahaan pertambangan batubara di Kutai Barat, dengan memahami peta kekuatan dan pengaruh sosial politik dan sosial kebudayaan, diharapkan dapat melaksanakan program CSR dengan lebih baik dan benar-benar membuat masyarakat dan segenap stakeholers merasakan manfaat kehadiran dari perusahaan itu.

Pemetaan sosial diperlukan terhadap masyarakat yang berkaitan dengan kegiatan bisnis pertambangan batubara itu. Apalagi, masyarakat Kutai Barat memiliki latar belakang budaya yang khas, sistem pemerintahan yang sangat dipengaruhi oleh sistem budaya dan adat, dan sejumlah kekuatan sosial kemasyarakatan yang beraneka ragam. Pemetaan sosial atau social mapping adalah upaya untuk mengetahui seberapa besar kekuatan dan pengaruh sendi-sendi kehidupan masyarakat, terutama yang berkaitan dengan sosial politik dan sosial budaya. Penelitian pemetaan sosial tersebut dilakukan di Kabupaten Kutai Barat, Kalimatan Timur. Sebuah kabupatenn yang sedang giat-giatnya mengundang para investor untuk melakukan ekploitasi tambang batubara di wilayahnya. Di kabupaten itu baru ada dua perusahaan yang sudah melakukan penggalian pertambangan batubara yakni PT Gunung Bayan Pratama dan PT Trubaindo Coal Mining. Namun, lokasi kedua perusahaan belum seberapa dibandingkan dengan keseluruhan kabupaten Kutai Barat yang diduga memiliki potensi yang besar dalam hal kandungan (deposit) batubara. Kabupaten Kutai Barat memiliki potensi hasil pertambangan batubara cukup besar. Dari 21 kecamatan, sedikitnya ada 8 kecamatan yang memiliki kandungan batubara yang secara ekonomis layak dieksploitasi.

Untuk memulai operasi pertambangan batubara, kiranya tidaklah cukup hanya melakukan survei untuk mengetahui kandungan batubara yang layak dieksploitasi secara ekonomis atau tidak. Perusahaan juga mesti mengetahui secara persis kondisi sosial kemasyarakatan, sosial politik, dan sosial budaya. Faktor-faktor tersebut, kalau tidak dikelola dengan baik, bisa memunculkan masalah atau konflik yang akan makan biaya tidak sedikit atu bisa menjadi gangguan yang serius, dan secara potensial bisa menghambat proses operasi pertambangan. Untuk mengidentifikasi berbagai dampak itu, perlu dilakukan penelitian atau survei sosial yang berkaitan dengan aneka dampak yang mungkin terjadi itu. Karena masalah yang melingkupi kegiatan itu kompleks, maka perlu dilakukan pemetaan sosial (social mapping). Pemetaan sosial (social mapping) didefinisikan sebagai proses penggambaran masyarakat yang sistematik serta melibatkan pengumpulan data dan informasi mengenai masyarakat termasuk di dalamnya profile dan masalah sosial yang ada pada masyarakat tersebut. Merujuk pada Netting, Kettner dan McMurtry (1993), pemetaan sosial dapat disebut juga sebagai social profiling atau "pembuatan profile suatu masyarakat". 
Perlu dicatat bahwa tidak ada aturan dan bahkan metode tunggal yang secara sistematik dianggap paling unggul dalam melakukan pemetaan sosial. Prinsip utama bagi para praktisi pekerjaan sosial dalam melakukan pemetaan sosial adalah bahwa ia dapat mengumpulkan informasi sebanyak mungkin dalam suatu wilayah tertentu secara spesifik yang dapat digunakan sebagai bahan membuat suatu keputusan terbaik dalam proses pertolongannya. Mengacu pada Netting, Kettner dan McMurtry (1993:68) ada tiga alasan utama mengapa para praktisi pekerjaan sosial memerlukan sebuah pendekatan sistematik dalam melakukan pemetaan sosial:

1. Pandangan mengenai "manusia dalam lingkungannya" (the person-in-environment) merupakan faktor penting dalam praktek pekerjaan sosial, khususnya dalam praktek tingkat makro atau praktek pengembangan masyarakat. Masyarakat dimana seseorang tinggal sangat penting dalam menggambarkan siapa gerangan dia, masalah apa yang dihadapinya, serta sumber-sumber apa yang tersedia untuk menangani masalah tersebut. Pengembangan masyarakat tidak akan berjalan baik tanpa pemahaman mengenai pengaruh-pengaruh masyarakat tersebut.

2. Pengembangan masyarakat memerlukan pemahaman mengenai sejarah dan perkembangan suatu masyarakat serta analisis mengenai status masyarakat saat ini. Tanpa pengetahuan ini, para praktisi akan mengalami hambatan dalam menerapkan nilai-nilai, sikap-sikap dan tradisi-tradisi pekerjaan sosial maupun dalam memelihara kemapanan dan mengupayakan perubahan.

Masyarakat secara konstan berubah. Individu-individu dan kelompok-kelompok begerak ke dalam perubahan kekuasaan, struktur ekonomi, sumber pendanaan dan peranan penduduk. Pemetaan sosial dapat membantu dalam memahami dan menginterpretasikan perubahan-perubahan tersebut (Edi Suharto dalam makalah Metode dan Teknik Pemetaan Sosial). Pemetaan sosial dimaksudkan untuk melihat dan mengetahui keadaan masyarakat sekitar daerah operasional pertambangan, dan kemudian perusahaan melakukan need assessment, atau mencari tahu kebutuhan dan tuntutan masyarakat yang bisa diberikan agar tidak menjadi gangguan dimasa depan. Selain itu, dengan social mapping tersebut, diharapkan bisa menjadi bahan masukan bagi perusahaan agar bisa mengambil sikap dan menghadapinya dengan cara yang tepat sasaran.

Social mapping (pemetaan sosial) selain dilakukan untuk menemu-kenali potensi sumber daya dan modal sosial masyarakat, juga dapat dilakukan untuk mengenal stakeholder dalam kaitannya dengan keberadaan dan aktivitasnya, bukan hanya yang berpotensi untuk diajak bekerjasama tetapi juga yang berpotensi untuk menghambat pelaksanaan program ke depan. Pada dasarnya, setiap pelaku (individu/ kelompok) memiliki cara pandang yang berbeda terhadap suatu hal yang terdapat dalam lingkungan sosial, yang didasari oleh faktor-faktor psiko-histori dan motif kepentingan yang berada dalam dirinya. Faktor ini akan mempengaruhi pelaku tersebut dalam menginterpretasikan situasi terakhir hingga proses perumusan tindakan.

\section{Metode Penelitian}

Metode penelitian dan teknik pemetaan sosial biasanya meliputi survei formal, pemantauan cepat (rapid appraisal) dan metode partisipatoris (participatory method) (LCC, 1977; Suharto, 1997; World Bank, 2002). Dalam wacana penelitian sosial, metode survei formal termasuk dalam pendekatan penelitian makro-kuantitatif, sedangkan metode pemantauan cepat dan partisipatoris termasuk dalam penelitian mikro-kualitatif (Suharto, 1997). Pemetaan sosial adalah satu kegiatan yang dilakukan untuk menemu-kenali kondisi sosial budaya masyarakat setempat. Kondisi sosial budaya yang dimaksud mencakup antara lain: (1) Nilai-nilai apakah yang dianut oleh masyarakat secara dominan, yang mampu menggerakkan masyarakat; (2) Kekuatan-kekuatan sosial apakah yang mampu mendatangkan perubahan-perubahan sehingga masyarakat dapat berubah dari dalam diri mereka sendiri; (3) Karakter dan karakteristik masyarakat seperti apa, khususnya dalam menyikapi intervensi social; (4) Pola informasi, komunikasi, yang terjadi di tengah masyarakat, baik penyebaran informasi 
maupun dalam kerangka pembelajaran; (5) Kekuatan-kekuatan sosial yang dominan di dalam kerangka perubahan social; dan (6) Faktor-faktor lingkungan apakah yang berpengaruh terhadap sikap dan perilaku masyarakat.

Sebelum melakukan penelitian lapangan untuk melakukan penelitian pemetaan sosial tersebut, terlebih dahulu dilakukan penelitian data sekunder mengenai Kutai Barat dan daerah-daerah yang memiliki potensi pertambangan batubara secara ekonomis. Pemetaan berdasarkan data sekunder tersebut dilakukan dengan menghimpun data yang berkaitan dengan Kutai Barat. Peta Kutai Barat, baik secara geografis, demografis, sosial politik, maupun sosial kebudayaan. Pengolahan data sekunder sebagai bagian dari pemetaan sosial tersebut memiliki peran penting sebagai kerangka atau acuan dasar untuk melakukan pemetaan sosial politik, keamanan dan kebudayaan secara lebih rinci di lokasi dan sekitar areal pertambangan. Gambaran secara umum yang meliputi keseluruhan Kabupaten Kutai Barat tersebut diharapkan bisa membantu memberikan konteks yang lebih tepat untuk pemetaan sosial lebih rinci di lokasi dan sekitar areal pertambangan batubara.

\section{Metode Pemantauan Cepat (rapid appraisal methods)}

Metode penelitian yang dipergunakan dalam survei pemetaan sosial ini adalah "Metode Pemantauan Cepat" (rapid appraisal methods). Metode ini merupakan cara yang cepat untuk mengumpulkan informasi mengenai pandangan dan masukan dari populasi sasaran dan stakeholders lainnya mengenai kondisi sosial kemasyarakatan, sosial politik dan sosial kebudayaan atas kegiatan pertambangan batubara di Kutai Barat tersebut. Metode pemantauan cepat tersebut meliputi: (1) Wawancara Informan Kunci (Key Informant Interview); (2) Pengamatan Langsung (Direct Observation); (3) Pengolahan data sekunder; dan (4) Survei Kecil (Mini-Survey).

Langkah-langkah tersebut diambil terutama untuk mengidentifikasi narasumber terlebih dahulu. Narasumber yang dipilih adalah mereka yang memiliki akses, merepresentasikan suatu kelompok tertentu, memahami masalah dan tentu saja yang bersangkutan bersedia untuk menjadi narasumber penelitian (Lihat Tabel 1: Kerangka Pemahaman Masyarakat dan Masalah Sosial). Setelah itu, penelitian menentukan karakteristik masyarakat yang berada di daerah sasaran, baik dengan wawancara langsung maupun dengan mewawancarai narasumber yang bisa mendeskripsikan dan merepresentasikan masyarakat itu. Penelitian merekam dan memahami nilai-nilai dominan yang meliputi nilai budaya, tradisi, keyakinan dari kelompok atau individu yang menganut nilai tersebut, dan konrlik nilai yang terjadi pada populasi sasaran. Selanjutnya adalah mengidentifikasi mekanisme 'penindasan' yang tampak dan formal seperti perbedaan yang terlihat dalam anggota populasi sasaran. Apa pula kekuatan populasi sasaran yang dapat diidentifikasi, dan bagaimana kekuatan tersebut mampu mendukung pemberdayaan. Penelitian pemetaan sosial juga mengarah kepada memahami lokasi kekuasaan, sumber pendanaan, pemimpin yang kuat dan berpengaruh dalam masyarakat, tipe kekuasaan yang mempengaruhi jaringan masyarakat dan pelaku bisnis batubara, dan lain-lain. Penelitian juga mengidentifikasi struktur dengan memahami peta kekuasaan dan mengidentifikasi pusat-pusat kekuasaan, dan pengaruh mereka terhadap masyarakat dan berbagai kegiatan yang berkaitan dengan bisnis pertambangan batubara. 
Tabel 1 Kerangka Pemahaman Masyarakat dan Masalah Sosial

\begin{tabular}{|c|c|}
\hline Fokus & Tugas \\
\hline A. Pengidentifikasian Populasi Sasaran & $\begin{array}{l}\text { 1. Memahami karakteristik anggota } \\
\text { populasi sasaran. }\end{array}$ \\
\hline B. Penentuan Karakteristik Masyarakat & $\begin{array}{l}\text { 2. Mengidentifikasi batas-batas } \\
\text { masyarakat. } \\
\text { 3. Menggambarkan masalah-masalah } \\
\text { sosial } \\
\text { 4. Memahami niai-nilai dominan. }\end{array}$ \\
\hline C. Pengakuan Perbedaan-Perbedaan & $\begin{array}{l}\text { 5. Mengidentifikasi mekanisme- } \\
\text { mekanisme penindasan yang tampak } \\
\text { dan formal. } \\
\text { 6. Mengidentifikasi bukti-bukti } \\
\text { diskriminasi. }\end{array}$ \\
\hline D. Pengidentifikasian Struktur & $\begin{array}{l}\text { 7. Memahami lokasi-lokasi kekuasaan. } \\
\text { 8. Menentukan ketersediaan sumber. } \\
\text { 9. Mengidentifikasi pola-pola } \\
\text { pengawasan sumber dan pemberian } \\
\text { pelayanan. }\end{array}$ \\
\hline
\end{tabular}

Sumber: Netting, Kettner dan McMurtry (1993:69)

\section{Langkah-langkah Penelitian}

Untuk memudahkan pelaksanaan penelitian, maka urutan penelitian dilakukan yaitu (1) menghimpun dan mengolah data sekunder tentang Kabupaten Kutai Barat dalam kaitannya dengan kegiatan pertambangan di kabupaten itu; (2) melakukan penghimpunan data primer ke lokasi sasaran dengan melakukan wawancara tokoh informan kunci, observasi lapangan, dan survei kecil; dan (3) mengolah data dan menganalis serta menyusun rangkuman atau kesimpulan.

\section{Langkah I Pengolahan Data Sekunder}

Tahap pertama penelitian dilakukan dengan mengolah data sekunder yang diperoleh dari berbagai sumber, baik data tertulis maupun data online. Data tersebut berkaitan dengan Kabupaten Kutai Barat, latar belakang historis, geografis, sosial politik maupun sosial kebudayaan. Pengolahan data sekunder tersebut dimaksudkan untuk lebih memberikan kerangka atau latar belakang atas penelitian lebih rinci mengenai pemetaan sosial di daerah pertambangan batubara.

Kabupaten Kutai Barat, dengan ibukota Sendawar, merupakan kabupaten pemekaran yang ditetapkan berdasarkan Undang-Undang Nomor 47 Tahun 1999 tertanggal 4 Oktober 1999. Berdasarkan data topografi, Kutai Barat memiliki keluasan wilayah 316.287.000 hektare (31.628,70 kilometer persegi), atau meliputi 15\% dari total Provinsi Kalimantan Timur. Landscape Kutai Barat didominasi oleh lahan dengan topografi sangat curam (50,16\%) dan curam $(6,11 \%)$ dan selebihnya dengan kondisi datar, dan bergelombang. Wilayah dengan topografi pegunungan mencapai 1.586.552,08 hektare atau lebih dari 50\% dari luas seluruhnya tersebut, berada di bagian Barat Laut Kabupaten Kutai Barat. Sedangkan wilayah dengan topografi datar hanya sebesar $10,35 \%$ atau 327.400,84 hektare, terletak di bagian Tenggara wilayah itu. Wilayah berbukit dan bergunung dijumpai di bagian hulu Sungai Mahakam, terutama di Kecamatan Long Bagun, Long Pahangai, dan Long Apari.

Secara Administratif Kabupaten Kutai Barat mempunyai 21 kecamatan yang terbagi menjadi 238 kampung. Secara demografis, jumlah penduduk adalah 177.133 jiwa (2009). Mayoritas penduduk kabupaten itu adalah Masyarakat Adat yang terdiri dari bermacam suku, bahasa, adat istiadat dan kultur. Di antaranya suku Dayak Tunjung (tinggal di dataran tinggi Barong Tongkok, Melak, Sekolaq 
Darat, Tering, Linggang Bigung. Suku Dayak Benuaq berada di dataran tinggi dan pesisir seperti Damai, Nyuatan, Siluq Ngurai, Muara Pahu, Jempang, Bentian Besar dan Bongan. Selain itu masih ada lagi suku Dayak Bahau, Punan dan Bakumpai, Penihing, Aoheng, Soputan, Bukat, dan Kenyah. Dari berbagai suku itu, Dayak Benuaq yang mendominasi di seluruh Kabupaten Kutai Barat.

Sektor pertambangan merupakan penyumbang terbesar kepada Produk Domestik Regional Bruto (PDRB) Kutai Barat, sekitar 47,43\%. Pertumbuhannya, antara tahun 2001 sampai 2007 sekitar 10,21\% per tahun. Tahun 2004 pertumbuhannya sempat turun menjadi 7,57\% karena penutupan tambang emas PT Kelian Equatorial Mining (KEM) setelah 10 tahun beroperasi. Sedang batubara mengalami fluktuasi. Tahun 2003 produksinya sekitar 3.3 juta ton, tahun 2006 melonjak tiga kali menjadi 10,7 juta ton, dan 2007 turun lagi menjadi 7,8 juta ton.

Kutai Barat memiliki berbagai macam sumberdaya tambang dengan jumlah besar seperti emas, batubara, antimonit, besi, perak, batu gamping, intan, kaolin, kristal, pasir kuarsa dan tembaga. Namun demikian, secara umum produk unggulan adalah emas, batubara dan perak. Produksi emas mencapai 10.019 ton dan perak 9.032 ton pada tahun 2005 .

Tabel 2 Kabupaten Kutai Barat

\begin{tabular}{|ll|}
\hline Ibukota & $:$ Sendawar \\
Bupati & $:$ Ismael Thomas, SH \\
Wakil Bupati & $:$ H. Didik Effendi, S.Sos \\
Luas wilayah & $: 316.287 .000$ hektare \\
Penduduk & $: 177.133 \mathrm{jiwa}$ \\
Kepadatan & $: 4,12 \mathrm{jiwa} / \mathrm{km}^{2}$ \\
Kecamatan & $: 21$ \\
Desa & $: 238$ \\
\hline
\end{tabular}

Kutai Barat memiliki prasarana (infrastruktur) jalan sebagai sarana penghubung di bidang trasportasi darat. Jalan merupakan salah satu unsur yang sangat penting dalam memperlancar kegiatan perekonomian masyarakat. Status jalan yang ada di Kabupaten Kutai Barat menurut data tahun 2008 terdiri dari jalan Negara/ Nasional, Provinsi dan Kabupaten. Menurut ukuran panjang, jalan di Kabupaten Kutai Barat terdiri dari jalan nasional sepanjang 48 km, jalan provinsi 402,5 km dan jalan Kabupaten 747,96 km.

Perhubungan dan transportasi: merupakan sektor pendukung yang sangat mutlak keberadaannya. Sebagai media pemindah barang maupun kegiatan dari suatu tempat ketempat lain. Kabupaten Kutai Barat yang sebagian besar wilayahnya daratan, memiliki sistem tranportasi dan perhubungan darat, baik dengan jalan maupun sungai. Hingga tahun 2008 terdapat 2 (dua) bandar udara perintis di Kabupaten Kutai Barat yakni Bandar Udara Melalan yang terletak di Kecamatan Barong Tongkok dan Bandar Udara Data Dawai di Long Pahangai dengan panjang landasan pacu antara 450 meter sampai 500 meter yang hanya dapat di darati pesawat sekelas Cessna.

Sedangkan peta politik, seperti tercermin dalam perolehan kursi tingkat DPRD II (lihat Tabel 3) dalam Pemilihan Umum 2009 yang lalu, Partai Demokrasi Indonesia Perjuangan (PDI-P) mendapat dukungan sebagian besar masyarakat Kutai Barat. PDI-P memperoleh 9 kursi, diikuti oleh Partai Golkar (5 kursi) dan Partai Demokrat (5 kursi). Selebihnya, tersisa 6 kursi dibagi bersama oleh partaipartai yang tergabung dalam Fraksi Amanat Hati Bangsa (PAN, Hanura, dan PBB). 
Tabel 3 Komposisi Fraksi DPRD II Kutai Barat hasil Pemilu 2009

\begin{tabular}{llc}
\hline No & \multicolumn{1}{c}{ Nama Fraksi } & Jumlah Kursi \\
\hline 1 & Fraksi PDI Perjuangan & 9 \\
2 & Fraksi Partai Golkar & 5 \\
3 & Fraksi Partai Demokrat & 5 \\
4 & Fraksi Amanat Hati Bangsa (PAN, Hanura, PKB) & 6 \\
\hline
\end{tabular}

Awal tahun 2011 akan dilakukan Pemilu Kepala Daerah. Bupati incumbent, Ismael Thomas, sudah siap-siap untuk ikut terjun ke dalam kancah pemilu tersebut. Kemenangannya akan ditentukan oleh pola koalisi dengan partai lain dan juga tingkat elektibilitasnya oleh rakyat secara langsung. Soalnya kalau hanya maju dengan partai sendiri (PDIP), di atas kertas, ia belum bisa memperoleh suara untuk memenangkan pemilu kepala daerah itu.

\section{Peta Pertambangan Batubara}

Kandungan batubara yang dianggap layak ditambang secara ekonomis di Kabupaten Kutai Barat berada di 8 kecamatan yakni Kecamatan Damai, Jempang, Siluq Ngurai, Muara Lawa, Muk Manor Bulat, Long Irang Bongan, Bentian Besar, Laham (Lihat Gambar 1: Peta Geografis). Hingga kini baru ada 2 (dua) perusahaan besar yang sudah melakukan produksi yaitu PT Gunung Bayan Pratama Coal Blok II di Kecamatan Muara Pahu dengan areal 17.740 hektare. Gunung Bayan juga mempunyai areal pertambangan di Blok I, seluas 18.250 di Kabupaten Kutai Timur. Sementara PT Trubaindo Coal Mining memiliki areal pertambangan di kecamatan Muara Lawa sekitar 23.650 hektare.

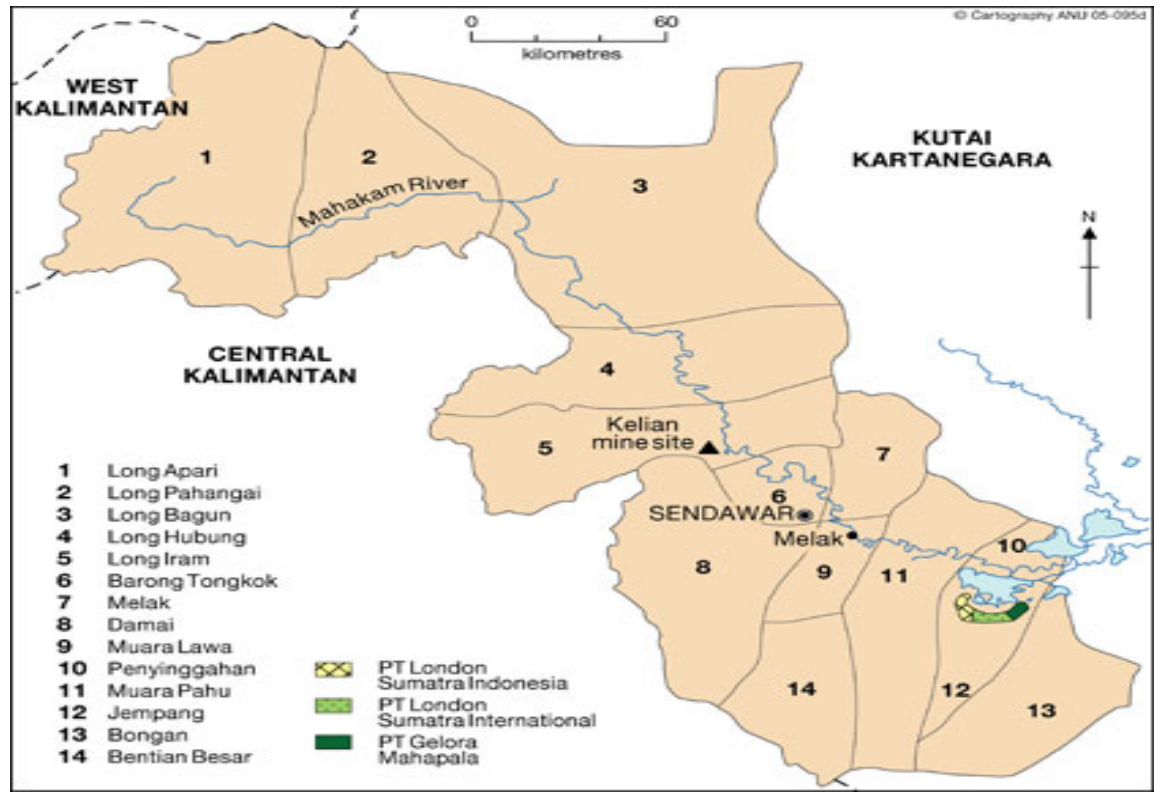

Gambar 1 Peta Geografis

Saat ini, di kecamatan Muara Lawa dan Siluq Ngurai sedang dilakukan eksplorasi dengan melakukan pengeboran untuk mendeteksi kandungan batubara oleh sebuah perusahaan tambang batubara, dan masih dalam proses untuk pengurusan perizinan dari Pemda Kabupaten Kutai Barat. 
Total areal yang dieksplorasi sekitar 50.000 hektar. Perusahaan batubara yang sudah melakukan penggalian di 4 (empat) lokasi di Kabupaten Kutai Barat adalah (1) PT Gunung Bayan Pratama Coal di Kampung Muara Tae, Kecamatan Jempang, dengan sistem open feet (kupas); (2) PT Gunung Bayan Pratama Coal di Kampung Muara Pahu, Kecamatan Muara Pahu, menggunakan sistem pelabuhan Stan Croucer; (3) PT Trubaindo Coal Mining (Banpu), lokasi kerja di kampung Lambing, Kecamatan Muara Lawa, menggunakan sistem open feet (kupas); (4) PT Trubaindo Coal Mining (Banpu) di Kecamatan Bentian Besar, menggunakan sistem open feet (kupas).

\section{Langkah 2: Penelitian Lapangan}

Penelitian lapangan dilakukan tanggal 21-29 Juni 2010. Peneliti dibantu oleh tim yang terdiri dari 3 wartawan Tribun Kaltim dari Balikpapan dan Sendawar dengan tugas membantu melakukan wawancara dan observasi lapangan. Tim peneliti berada di Kecamatan Siluq Ngurai, Kampung Dingin dan Lambing, Kecamatan Muara Lawa, Muara Pahu, Jempang, Bentian Besar, serta ibukota Kabupaten Kutai Barat, Sendawar. Narasumber yang diidentifikasi dan dipilih adalah mereka yang merepresentasikan kelompok masyarakat yang berhubungan dengan daerah dan kelompok masyarakat yang berhubungan dengan proyek pertambangan batubara. Mereka rata-rata juga memiliki pengetahuan dan dikenal mempunyai keterlibatan atau kepedulian terhadap kegiatan pertambangan batubara itu. Narasumber yang dipilih dan diwawancarai adalah mereka yang memenuhi kriteria antara lain merepresentasikan masyarakat yang berhubungan dengan kegiatan pertambangan batubara itu, memiliki kompetensi dan memahami masalah, serta memiliki pengalaman dalam kehidupan sosial dalam kaitan dengan masyarakat di lokasi dan sekitar pertambangan batubara itu.

\section{Wawancara Informan Kunci}

Terdapat 6 informan kunci yang diwawancara, yaitu Syanghai, Don Bosko Bulor, F. Darin, Robertus Syahrun, Saripudin, SE, dan Polres Kutai Barat. Syanghai adalah seorang tokoh masyarakat desa Lembin, Kecamaan Muara Lawa. Beliau juga seorang pemuka adat suku Dayak Benuaq, anggota DPRD II Kutai Barat dari Fraksi Partai Golkar, berasal Kecamatan Muara Lawa, dan memiliki hubungan keluarga dan adat suku dengan penduduk yang terkena proyek pertambangan batubara di Kampung Dingin, Muara Lawa.

Don Bosko Bulor merupakan anggota DPRD II Kabupaten Kutai Barat dari Fraksi PDIP, tokoh masyarakat, bekas aktivis LSM, tokoh Gereja Katolik, tinggal dan mewakili daerah pemilihan Muara Lawa. F. Darin adalah kepala Badan Pelayanan Perijinan Terpadu (BP2T). Dia yang memproses dan merekomendasikan berbagai perizinan untuk eksplorasi dan eksploitasi pertambangan batubara di Kutai Barat sebelum disetujui oleh Bupati Kutai Barat. Dia juga bekas camat Muara Pahu yang berpengalaman mencegah ketidakpuasan warga dengan menjembatani warga dan perusahaan PT Gunung Bayan. Sebagai pejabat pemerintah, ia tinggal di Sendawar.

Robertus Syahrun seorang camat Muara Lawa yang membawahi sebagian besar areal pertambangan yang sudah dikelola PT Trubaindo (Banpu) dan calon areal pertambangan yang sedang dalam proses eksplorasi. Saripudin, SE. adalah kepala Bidang Analisa dan Promosi, Badan Pelayanan Perijinan Terpadu (BP2T), Kutai Barat, di Sendawar. Dia yang bertanggungjawab dalam meneliti dan menganalisis apakah perusahaan dan lokasi tertentu layak mendapat izin atau tidak. Sementara itu, Polres Kutai Barat di Sendawar maupun Polsek di beberapa kecamatan yang memiliki areal tambang batubara, untuk memetakan siapa saja yang potensial menggerakkan masyarakat untuk mengganggu keamanan, baik di lingkungan areal tambang maupun di luar pertambangan.

\section{Observasi langsung (direct observation)}

Peneliti melakukan pengamatan dan reportase di areal pertambangan batubara PT Gunung Bayan, masyarakat di lokasi pertambangan Kampung Dingin, kondisi masyarakat di sekitar lokasi 
pertambangan PT Trubaindo di Kecamatan Muara Lawa, dan kehidupan para pekerja pertambangan yang menginap di kota Muara Lawa, serta perkampungan yang diperkirakan akan menjadi lokasi pertambangan batubara.

\section{Penelitian Kelompok Kecil (mini survey) dengan sekelompok masyarakat}

Penelitian kelompok kecil dengan sekelompok masyarakat dibagi menjadi beberapa bagian, yaitu (1) penduduk Kampung Dingin: sampel penduduk yang sudah terkena penggalian oleh PT Trubaindo (Banpu) dan sebagian lagi akan terkena proyek yang sedang dalam tahap eksplorasi oleh perusahaan lain; (2) beberapa karyawan pertambangan yang mengontrak rumah di sekitar hotel Rahmat, Muara Lawa; (3) kelompok warga masyarakat di sekitar areal pertambangan di Siluq Ngurai; (4) pemuka suku, adat dan agama: yang dianggap menjadi panutan atau teladan dalam hal bersikap menghadapi berbagai kendala dan otoritas untuk mempertahankan adat dan budaya Dayak Benuaq.

Narasumber yang ditemui dan diwawancarai, sesuai dengan dasar teorinya, dipilih dari mereka yang dinilai bisa mewakili pihak-pihak yang terlibat atau mengetahui persoalan yang berkaitan dengan analisis dampak sosial kemasyarakatan, sosial politik, dan sosial keamanan di lokasi pertambangan yang berada di areal pertambangan di Kabupaten Kutai Barat, Kalimantan Timur.

\section{Penelitian Kecil}

\section{Karyawan pengeboran}

Karyawan yang melakukan pengeboran, sebagian berasal dari Jakarta atau Jawa. Mereka melakukan pemboran untuk mengetahui lokasi mana yang mengandung batubara yang layak digali. Ketika mereka masuk lokasi, mereka ditemani oleh tim dari perusahaan. Mereka juga diantar oleh pemilik tanah. Namun, sering ada pihak lain yang sering mengikutinya. Mereka biasanya dari luar kampung atau juga dari kampung yang bersangkutan. Namun, sebenarnya mereka tidak berurusan dengan kepemilikan tanah. Maka, pihak perusahaan sering membawa polisi untuk mengawal mereka untuk menghindari hal-hal yang tak diinginkan seperti bentrok antara pemilik tanah dan orang-orang yang ikut mengawal itu. Berapa uang yang mereka minta? Bervariasi. Katanya, hal itu urusan petugas yang mengawal dari perusahaan. Kehadiran mereka sering menganggu. Kadang minta jatah dari pemilik tanah, tapi seringnya mereka minta jasa 'pengamanan' dari perusahaan.

\section{Penduduk dari Kampung Dingin}

Mereka memang mendengar, pernah terjadi perkelahian keluarga di tempat lain, sampai ada yang meninggal. Perkelahian tersebut biasanya dipicu oleh perebutan hak waris atas tanah yang mereka miliki. Rebutan warisan tersebut, mestinya diselesaikan di tingkat keluarga. Namun, sering penyelesaian di tingkat keluarga tidak memuaskan salah satu pihak setelah perolehan ganti rugi mereka ternyata berbeda dengan pihak lain. Di Kampung Dingin, sebagian besar mengikuti apa yang digariskan pihak kecamatan. Mereka melakukan negosiasi harga tanah yang akan dijadikan areal pertambangan. Asalkan harga kompensasi sesuai dengan permintaan rakyat, kiranya tidak akan terjadi gejolak di masa datang.

Gejolak yang akan muncul diperkirakan justru datang dari pihak luar yang memanas-manasi agar uang yang dibayarkan oleh perusahaan bisa lebih besar lagi. Selain itu, di antara warga juga bisa saja terjadi konflik apabila penyelesaian batas tanah mereka tidak jelas. Makanya, perusahaan harus memastikan bahwa penetapan ganti rugi atau kompensasi harus benar-benar jelas ketika membayarkan kompensasi. Jangan sampai, uang kompensasi sudah dibayarkan, lantas ada pihak lain yang mengklaim bahwa tanah itu miliknya yang belum pernah dibayar. 
Bagi pemilik tanah, asal dibayar sesuai dengan kesepakatan, mereka merasa tidak akan ada masalah. Mungkin masalah akan muncul apabila ada pencemaran limbah. Air yang dibuang tidak dijernihkan seperti ketentuan pengolahan limbah, rusaknya jalan untuk lintasan angkutan pertambangan, penanaman bekas lokasi pertambangan dengan tanaman yang dijanjikan. Selain itu, janji-janji seperti CSR diharapkan dipenuhi. Soalnya, janji dari perusahaan sudah dipandang sebagai hak mereka. Pelibatan penduduk setempat memang baik dan hal itu membuat warga senang menerima kehadiran perusahaan pertambangan itu. Namun, kalau para pekerja itu tidak disiapkan secara mental oleh perusahaan, misalnya ditegur, diberhentikan karena tidak disiplin, dan lain-lain, akan mengundang kerawanan sosial. Penyelesaian kontrak, PHK, dll, sering mengundang kerawanan keamanan seperti demo, pengaduan ke Dinas Tenaga Kerja, dll.

\section{Penduduk di sekitar lokasi Kuasa Pertambangan (KP)}

Warga di sekitar lokasi Kuasa Penambangan sering kali mendengar dan tahu ada perusahaan pertambangan akan beroperasi, akan tetapi biasanya warga tidak mengetahui secara pasti, siapa dan kapan serta bagaimana tambang itu beroperasi dan bekerja. Warga masyarakat biasanya memperoleh isu atau kabar tentang rencana perusahaan tambang beroperasi melalui penyebaran dari mulut ke mulut. Tidak pernah mendapatkan informasi secara resmi atau formal lewat surat atau pengumuman dari aparat berwenang, baik itu dari Kabupaten, Dinas, Camat atau desa/ keluarahan. Biasanya, beberapa tokoh masyarakat membawa informasi itu kepada warga yang terdekat, kemudian kabar itu menyebar di antara penduduk.

Kehadiran perusahaan pertambangan akan melibatkan mereka? Belum tentu. Warga mengaku memang ada beberapa orang warga desa setempat yang masuk sebagai tenaga kerja. Biasanya sebagai wakar (tenaga) pengamanan, karena dianggap faham dan mengetahui tentang kebiasaan suku dan warga setempat. Mereka dijadikan pekerja perusahaan tambang untuk menghadapi warga setempat apabila ada protes atau komplain dari warga yang merasa terganggu oleh usaha penambangan itu. Kalau ada pekerja tetap di perusahaan tambang biasanya adalah orang-orang yang dari awal sudah mengetahui tentang informasi tambang di desa dan memang diajak. Begitu ada perusahaan tambang yang beroperasi, maka beberapa warga (penduduk) setempat melamar kerja melalui tokoh atau orang dalam untuk diperkejakan. Akan tetapi sering kali mereka kecewa, karena selalu saja ditolak karena tidak mempunyai kemampuan kerja yang mamadai, tidak punya skill di bidang pertambangan atau bahkan untuk urusan kebersihan sekalipun. Warga setempat tidak mempunyai kebiasan menangkap peluang bila ada perusahaan tambang beroperasi di wilayahnya. Warga setempat tidak mempunyai kebiasaan berjualan, meski membuka warung sekalipun. Warung-warung ataupun segala macam jenis jasa di sekitar tambang biasanya dikuasai oleh warga pendatang. Hampir setiap warung yang ada di lokasi tambang biasanya dilayani oleh warga pendatang yang mempunyai koneksi atau hubungan dengan orang dalam. Mereka biasa memberi jasa catering ataupun warung kecil.

Sering kali warga hanya dijadikan alat oleh beberapa tokoh baik tokoh politik, agama, adat atau LSM untuk melakukan protes, unjuk rasa terhadap perusahaan tambang untuk menuntut urusan tertentu. Mulai dari pembebasan tanah, pembagian fee, CSR dan menuntut pekerjaan kepada perusahaan. Warga setempat baru bergerak melakukan aksi, apabila ada pemimpin atau provokator dari orang-orang tertentu. Warga baru melakukan aksi apabila ada hal-hal yang memang mengganggu lingkungan hidup mereka. Misalnya kerusakan jalan, banjir akibat danau-danau yang diciptakan oleh penggalian tambang itu meluap, dan lain-lain. Mereka baru melakukan aksi protes, demo atau pemblokiran terhadap usaha penambangan bila terjadi banjir, debu bertebaran dan kerusakan jalan yang parah. Munculnya danau-danau raksasa belum menjadi prioritas aksi penuntutan sepanjang danau itu tidak menimbulkan akibat langsung kepada warga sekitar. Menurut pendapat warga sekitar yang tidak mendapatkan bagian apa-apa, berpendapat bahwa gangguan keamanan bagi suatu proyek terjadi apabila ada tokoh warga setempat yang merasa tidak dilibatkan dalam penggarapan proyek. Atau ada orang dari luar lokasi yang kemudian tidak mendapatkan keuntungan dari proyek tersebut. Biasanya mereka mengajak warga (penduduk) setempat untuk melakukan aksi. 
Yang menjadi concern masyarakat tetangga adalah dampak lingkungan yang akan terjadi, terutama apabila benar-benar mengganggu mereka. Begitu pula dengan dampak sosial yang sering muncul dari kegiatan pertambangan. Reaksi dari warga masyarakat biasanya muncul apabila proyek itu berdampak langsung dan mengganggu warga seperti tanah mereka dicaplok, banjir yang menimbulkan korban, empang atau sawah menjadi tidak berproduksi akibat tambang, dan lain-lain.

Kehadiran proyek pertambangan belum tentu mendatangkan untung bagi warga sekitarnya. Mereka senang karena ada tontonan baru, kegiatan pertambangan. Mereka berharap agar proyek pertambangan mampu memberikan manfaat kepada warga dan masyarakat sekitar, ada tetesan sekonominya. Bahkan pemerintah pun yang mendapatkan bagian dari pertambangan, diharapkan bisa membagikannya kepada warga yang tidak pernah menikmati proyek pertambangan. Misalnya, royalti yang diperoleh pemerintah hendaknya bisa dimanfaatkan untuk pengadaan infrastruktur yang bisa dinikmati segenap rakyat seperti jalan, listrik, pasar, kesehatan, pendidikan. Jangan sampai rakyat hanya menjadi penonton atas masyarakat yang bergelimang uang dan batubara berjuta ton yang mengalir ke hilir.

\section{Tokoh suku, adat, agama}

Seberapa besar pengaruh suku atau keluarga atau kerabat atas pelaksanaan proyek KP itu? Suku yang mendiami kawansan tambang batubara adalah suku Dayak Benuaq yang dikenal sebagai suku Dayak yang cukup maju pendidikannya. Tokoh yang terkenal adalah budayawan dan sastrawan Korrie Layun Rampan dan Mantan Wakil Gubernur Kaltim Jurnalis Ngayoh. Sekarang ini ada tokoh Benuaq yang aktif di KNPI Kaltim, Rapin Rabanni. Suku Dayak Benuaq jumlahnya sekitar 60\% dari total Suku Dayak di Kalimantan Timur. Dengan adanya proyek pertambangan, tentu ada adat atau budaya yang mungkin tercerabut. Hampir semua suku Dayak, termasuk Benuaq, habitatnya adalah budaya hutan. Mereka hidup dan mencari penghidupan di hutan. Begitu tambang dibuka, maka korban pertama adalah hilangnya habitat hutan, baik itu untuk kepentingan hidup Suku Dayak, maupun untuk habitat pelestarian flora dan fauna yang ada di dalamnya.

Adat istiadat dan tata krama diwariskan sama tuanya dengan keberadaan Suku Dayak Benuaq di Bumi. Suku Dayak Benuaq percaya bahwa sistem adat yang ada bukanlah hasil budaya, tetapi mereka mendapatkan dari petunjuk langsung dari Letalla melalui para Seniang maupun melalui mimpi. Orang Dayak Benuaq, percaya bahwa sIstem adatnya telah ada sebelum negara ini lahir Itu sebabnya mereka tidak menerima begitu saja pendapat yang mengatakan bahwa dengan lahirnya negara dan aturan dapat menghilangkan aturan Adat Istiadat Suku Dayak Benuaq. Setiap jengkal tanah untuk proyek ataupun tambang di wilayah itu selalu bersentuhan dengan tanah leluhur milik Suku Benuaq. Mereka selalu terlibat di dalam urusan ini. Hanya saja sejauh ini sikap suku Benuaq termasuk suku-suku Dayak lainnya cenderung berdamai, tidak terlalu merepotkan. Tetapi memang sesekali mereka melakukan aksi protes terkait dengan penggunaan lahan. Hutan dan segala isinya bagi Suku Dayak Benuaq merupakan benda/ barang adat. Itu sebabnya pengelolaannya harus berdasarkan system adat istiadat.

Pada zaman Orde Baru Suku Dayak Ben0aq mengalami zaman yang paling buruk. Hutan sebagai ibu pertiwi mereka disingkirkan dari orang Ben0aq dengan berdalih pada Undang-Undang terutama pada Undang-Undang Agraria. Sehingga rezim Orba dengan mudah memisahkan Suku Dayak Benuaq dengan sumber satu-satu penghidupan mereka saat itu yakni hutan. Ditambah lagi dengan disebarnya aparat keamanan yang menjadi tameng dari perusahaan-perusahaan pemegang HPH. Bagaimana adat dan kebudayaan mereka menghadapi kehadiran kegiatan pertambangan itu? Adat Suku Benuaq sangat toleransi terhadap pertambangan dan sejenisnya, meski mereka tahu dan sadar bahwa perusakan hutan akan mempengaruhi kehidupan mereka. Suku Benuaq tidak retensi terhadap masuknya unsur-unsur itu. Sejauh ini suku Benuaq tidak pernah menggunakan peraturan adat untuk menyelesaikan urusan dengan tanah, tambang dan perkebunan. Kalaulah ada, hukum adat hanya dijadikan sarana untuk melakukan negosiasi dengan pihak pertambangan-perkebunan sepanjang itu menyangkut hak tanah adat. 


\section{HASIL DAN PEMBAHASAN}

Berdasarkan data primer dan sekunder seperti disajikan dalam penelitian di atas, maka bisa diidentifikasi sejumlah masalah yang berkaitan dengan pemetaan sosial seperti dimaksudkan dalam tujuan dari penelitian tersebut.

\section{Pemetaan Sosial}

Pemetaan sosial dalam penelitian ini terbagi dalam 5 bagian, yaitu peta geografis, peta sosial politik, peta sosial kebudayaan, peta keamanan, dan peta kekuasaan.

\section{Peta Geografis}

Kutai Barat bisa dijangkau dengan jalan darat lewat Trans Kalimantan maupun lewat jalur sungai Mahakam. Infrastruktur jalan di seluruh kabupaten Kutai Barat secara relatif dapat dijangkau dengan cukup memadai.

\section{Peta Sosial Politik}

PDIP masih menguasai komposisi kekuatan sosial politik di kabupaten itu. Dua partai lainnya yang menempatiurutan berikutnya adalah Partai Golkar dan Partai Demokrat. Bupati yang sekarang memimpin Kutai Barat, Ismael Thomas, juga didukung oleh PDI-P. Bahkan dalam Pemilu Kepala Daerah bulan Januari 2011, Ismael Thomas masih akan tampil sebagai calon dengan pendukung utama PDP juga.

\section{Peta Sosial Kebudayaan}

Walaupun kepala adat tidak memiliki kekuasaan yang nyata dan besar, namun peranan sosial budaya sangat menonjol terutama yang berakaitan dengan pola berpikir (mindset), perilaku, sikap dan berbagai aktivitas sosial. Kebudayaan yang sangat diwarnai oleh adat suku Dayak Benuaq itu memiliki peran yang sangat menonjol bagi sistem pemerintahan kabupaten, kecamatan maupun desa, serta sikap dan perilaku rakyat dalam kehidupan sehari-hari. Orang Dayak Benuaq misalnya bersikap tidak mau terlalu banyak berurusan dengan polisi. Artinya, mereka tidak mau melakukan pelanggaran keamanan dan ketertiban masyarakat (kamtibmas). Namun kalau secara pribadi mereka diganggu oleh orang lain, mereka bisa bertindak menurut jalan pikirannya, yakni main tebas kepala dan kemudian datang ke polisi untuk menyerahkan diri. Demikian pula dalam kehidupan lain, mereka tidak mau repot-repot dengan urusan keamanan. Kalau adat atau desa mereka diganggu oleh kegiatan pertambangan batubara, atau hak-hak mereka tidak dipenuhi oleh pihak lain, mereka bisa bertindak bersama-sama untuk menghentikan operasi atau pengangkutan batubara, dan lain-lain. Tindakan semacam itu tidak perlu dengan pengaturan atau sepengetahuan kepala adat.

\section{Peta Keamanan}

Secara formal, polisi memegang kendali keamanan dan ketertiban masyarakat. Namun di balik itu, secara tidak formal, ada beberapa kelompok atau semacam preman yang menawarkan diri untuk jasa keamanan. Kelompok ini memang tidak formal sebagai subordinasi dari ormas kepemudaan atau laskar yang ada. Mereka kelompok yang boleh disebut independen yang menawarkan jasa pengamanan. Mereka tidak terlalu kuat karena komitmen mereka hanya dalam kaitan dengan uang. Mereka akan menjamin keamanan dan menjadi beking siapa saja yang mau membayarnya. 


\section{Peta Kekuasaan}

Peta kekuasaan dalam penelitian ini terdiri dari pemerintah daerah dan kepala adat (lihat Tabel 4). Pemerintah Daerah merupakan kekuatan yang paling nyata dan memiliki kekuasaan yang sangat besar. Kekuasaan tersebut mulai dari tingkat kabupaten, kecamatan, sampai kepala desa. Kabupaten sebagai pusat pemerintahan daerah menjadi pemegang kekuasaan untuk berbagai perizinan, peraturan daerah, anggaran, pajak, retribusi, dan berbagai instrumen kekuasaan eksekutif lainnya. Di bidang pertambangan batubara, dengan adanya PP 28 dan 29 (Februari 2010) tentang Pertambangan yang menyebutkan bahwa satu izin hanya untuk lahan yang tidak lebih dari 5.000 hektare, menunjukkan bahwa Pemerintah Daerah Tingkat II atau Kabupaten Kutai Barat memiliki kekuasaan yang menentukan untuk menerbitkan izin bagi kuasa pertambangan. Kekuasaan Pemda cukup besar dan menentukan bagi suatu perusahaan bisa mendapatkan izin atau tidak. Artinya, perusahaan yang mau membuka pertambangan batubara di Kutai Barat, tidak bisa main 'by pass' ke pusat untuk mendapatkan izin eksplorasi maupun eksploitasi.

Pemerintah Daerah Kutai Barat juga akan mengawasi dan mengendalikan perusahaanperusahaann yang beroperasi di wilayah itu. Baik dengan peraturan daerah maupun jajaran aparat yang melakukan pengawasan langsung. Retribusi, royalti, dan berbagai kutipan akan dipungut dari hasil tambang batubara yang akan diangkut keluar dari wilayah Kutai Barat. Dalam hal pengendalian keamanan dan ketertiban, pemerintah daerah mempunyai kendali yang sangat kuat. Polres dan aparat keamanan lainnya, tergantung kepada kordinasi yang dilakukan oleh pemerintah kabupaten. Kekuasaan eksekutif tersebut juga diturunkan ke jajaran mereka di lapis bawah seperti camat dan kepala desa. Camat adalah pelaksana dan tangan bupati yang berhubungan langsung dengan rakyat.

Sementara itu, kepala adat hanya memiliki wewenang di bidang ritual dan adat. Para kepala adat memang mendapat ruangan kantor di kantor kepala desa dan kecamatan, serta di kabupaten. Untuk kepala adat tingkat kepala desa dan kecamatan, mereka mendapat honor dari camat. Sedangkan Kepala Adat Besar di tingkat kabupaten diberi gaji lewat anggaran pemda. Para kepala adat diangkat berdasarkan ketentuan yang berlaku di pemerintahan kabupaten dengan syarat sudah tinggal di wilayah itu dalam waktu tertentu, dan tidak harus memiliki hubungan darah dengan kepala adat sebelumnya. Kepala adat, menurut akses kekuasaan, hanya menjangkau rakyat di bidang ritual dan adat atau kekeluargaan. Para kepala adat berada dibawah kordinasi kepala desa, camat atau bupati.

Tabel 4 Peta Pengaruh dan Kekuasaan

\begin{tabular}{llll} 
& \multicolumn{1}{c}{ Pengaruh } & \multicolumn{1}{c}{ Kekuasaan } & Pengaruh\&Kekuasaan \\
\hline Pemerintah Daerah & ADA & ADA & ADA \\
Kepala Adat & ADA & TIDAK ADA & - \\
Suku dan adat & ADA & TIDAK ADA & - \\
Partai Politik & ADA & TIDAK ADA & - \\
Polisi & TIDAK ADA & ADA & - \\
Kelompok penekan & ADA & TIDAK ADA & - \\
\hline
\end{tabular}

\section{Pemetaan Masalah}

Dalam penelitian ini, terdapat beberapa pemetaan masalah utama yang terjadi, yaitu (1) ganti rugi tanah warga; (2) pencemaran lingkungan hidup; (3) adat; (4) pungutan, retribusi, loyalti, dan lainlain; (5) premanisme; (6) tenaga lokal; (7) kesenjangan sosial; (8) perusahaan pertambangan mencari untung. 
Ganti rugi tanah warga merupakan masalah paling menonjol dan selalu menjadi pemicu gangguan sosial dan keamanan di berbagai areal pertambangan batubara adalah kompensasi atau ganti rugi tanah penduduk yang dianggap tidak adil dan fair. Kerawanan pertama adalah pertikaian antara keluarga atau pemilik/ pewaris tanah. Yang kedua adalah konflik antar kampung atau kecamatan karena sengketa tapal batas tanah yang akan dijadikan areal pertambangan. Dan yang ketiga adalah ketidak sepahaman atas pembayaran ganti rugi. Kadang perusahaan tidak menepati janji atau membayar lebih rendah, atau ada pihak lain yang meminta jatah, tapi bisa juga penduduk menuntut pembayaran lebih tinggi karena diprovokasi oleh pihak lain. Uang telah membuat keluarga pecah, tapi uang juga bisa membuat orang lain 'mengail di air keruh' untuk mempersoalkan kembali nilai ganti rugi atas tanah milik penduduk. Protes bisa berupa demonstrasi, blokade angkutan/ kegiatan operasional, penutupan, dan lain-lain.

Pencemaran Lingkungan Hidup, seperti gangguan atas lingkungan hidup, baik untuk warga yang berada di lokasi penggalian tambang maupun masyarakat di sekitar pertambangan, sering berdampak luas. Perusahaan harus menaati ketentuan pengolahan air limbah sehingga bersih sebelum dialirkan keluar, tidak membiarkan top soil atau lapisan muka tanah berceceran atau menimbun tanah penduduk, kerusakan jalan, debu, dan lain-lain. Di beberapa tempat, perusahaan pertambangan ada yang ditutup sementara karena tidak memperhatikan pengolahan limbah pertambangan dan gangguan kepada kenyamanan warga sekitar. Permasalahan dalam adat yaitu tanah adat yang sering menjadi masalah. Dengan dalih 'mengabaikan' atau melecehkan adat, perusahaan pertambangan bisa mendapat gangguan yang sinyifikan. Dengan dalih adat, maka rakyat akan mendapat dukungan luas untuk berkonflik dengan perusahaan. Biasanya, di balik alasan adat itu, ada masalah yang berkaitan dengan ganti rugi atau kompensasi tanah. Tanah milik adat pun bisa dibeli, tentu dengan harga yang mahal. Pemuka adat tidak secara langsung mampu mengendalikan warganya, terutama berkaitan dengan hak milik mereka. Adat hanya berurusan dengan keluarga dan ritual. Urusan tanah milik pribadi, sepenuhnya menjadi urusan dari keluarga atau individu yang bersangkutan.

Pungutan, retribusi, royalti, dan lain-lain, pemerintah daerah mengutip aneka pungutan dari perusahaan pertambangan. Ada kutipan resmi, tapi ada juga yang tidak resmi. Pungutan resmi dilandasi oleh peraturan daerah atau ketentuan lain yang lebih tinggi, secara resmi bisa dikontrol sebagai pendapatan daerah. DPRD II dan aparat pengawas lainnya bisa mengawasi penerimaan dari berbagai kutipan dan royalti resmi tersebut. Bahkan mereka juga bisa mengawasi penggunaannya. Sedangkan pungutan tak resmi sering menjadi masalah karena akuntabilitasnya layak dipertanyakan. Selain itu, perusahaan juga mesti menyiapkan dana cukup besar untuk urusan external relation tersebut, baik dengan tokoh politik, pemerintah, adat, LSM, dan kelompok penekan lainnya. Dengan adanya otoritas pemda kabupaten yang mengutip berbagai pungutan tersebut, dengan sendirinya Pemda adalah pemegang kekuasaan terbesar di wilayah Kutai Barat tersebut.

Premanisme, preman tidak harus bersumber dari organisasi massa yang sudah ada. Preman bisa timbul secara pragmatis karena uang. Masalahnya, mereka tak pernah puas dan selalu memakai berbagai cara untuk membuat suasana sedemikian rupa agar kehadiran mereka tetap doperlukan. Premanisme bisa mengganggu keamanan fisik sehari-hari di lokasi, tapi bisa pula berdampak pada maraknya aksi massa yang mereka gerakkan. Kendalanya, biaya untuk preman ini cukup besar. Preman bisa dari luar lokasi pertambangan, tapi bisa pula dari dalam areal pertambangan.

Tenaga lokal di beberapa areal pertambangan, tenaga setempat dialokasikan 60\%. Namun kebanyakan tenaga yang bisa direkrut dari warga setempat antara lain satpam, sopir, penggali, dll. Tenaga ahli tetap didatangkan dari luar daerah. Kalau kuota tidak terpenuhi, perusahaan akan kena protes. Namun kalau permintaan tenaga kerja itu dipenuhi, perusahaan bisa rugi besar karena semangat kerja orang lokal sangat terbatas. Kalau orang lain bisa 6-7 rit sehari, sementara sopir orang lokal paling 3-4 rit. Untuk itu, perusahaan harus mendidik mereka, baik skill maupun perilakunya, agar mereka siap bekerja dengan pihak lain yang mengawasi dan mengaturnya. Salah satu karakter orang disana adalah tidak sigap, bekerja seenaknya, dan tidak mau diatur-atur. 
Kesenjangan sosial yang menikmati booming pertambangan di Kutai Barat adalah pemilik tanah saja. Orang sekitar maupun orang lain hanya menjadi penonton ada orang yang tiba-tiba menjadi OKB alias orang kaya baru. Memang, mereka sekarang riang gembira karena mendapatkan ganti rugi, tapi apa yang mereka lakukan setelah tanah habis dikeruk dan tak mendapat penghasilan. Bisa saja terjadi setelah banjir duit, akan banjir air mata di masa datang. Banjir duit akan berdampak pada kesenjangan sosial, antara pemilik tanah yang bergelimang uang, dan orang lain di sekitar yang tetap miskin karena tak kebagian keceran. Apalagi pemerintah yang memperoleh pemasukan dari tambang. belum terlihat membuat infrastruktur yang bisa dinikmati rakyat banyak, seperti jalan, listrik, biaya pendidikan, kesehatan, dan lain-lain. Orang luar yang apatis terhadap kegiatan pertambangan akan cepat mendukung gerakan yang menentangnya apabila digerakkan oleh kelompok yang kredibel.

Jumlah personel polisi yang kecil, total polisi di Kutai Barat cuma 300 orang. Kalau terjadi gangguan keamanan, pengamanan utama adalah polisi. Namun karena jumlahnya tidak memadai, polisi bisa kebobolan. Apalagi kalau terjadi tindakan anarkis seperti merusak atau membakar peralatan penggalian, atau sampai terjadi bentrok sosial di lokasi. Polisi yang jumlah 300 orang dan tersebar di berbagai polsek itu, tak akan mampu mengatasi kalau terjadi kericuhan. Jarak dari lokasi dan markas mereka juga sangat jauh.

Perusahaan pertambangan mencari untung, perusahaan pertambangan dicitrakan hanya mencari keuntungan yang sebesar-besarnya. Bahkan perusahaan pertambangan dicitrakan arogan dan tamak (griddy). Mereka menekan biaya, termasuk biaya untuk kompensasi tanah dan biaya sosial lainnya. Sikap pelit seperti itu sering mengundang gejolak. Dengan menekan biaya kompensasi tanah, perusahaan menuai berbagai protes. Gerakan menyerang perusahaan paling gampang adalah mempersengketakan uang kompensasi, adanya pencemaran bagi lingkungan hidup, dan pelanggaran adat.

Tabel 5 Peta Masalah yang Mempunyai Potensi Menyulut Konflik

\begin{tabular}{lll}
\hline \multicolumn{1}{c}{ Masalah } & Potensi Konflik & \multicolumn{1}{c}{ Kondisi } \\
\hline Ganti rugi tanah & Besar sekali & Tidak terbuka, adil, fair \\
Pencemaran lingkungan hidup & Besar & Terjadi pencemaran dan gangguan bagi rakyat \\
Adat & Besar & Ada pelanggaran hak-hak adat \\
Premanisme & Bisa terjadi & Tak diberi uang dan pekerjaan \\
Tenaga lokal & Bisa terjadi & Ada teguran, PHK, kontrak berakhir,dll. \\
Kesenjangan sosial & Bisa terjadi & Rakyat sekitar tak mendapat CSR pemberdayaan \\
Perusahaan arogan/ cari untung & Besar & Tak peduli dengan nasib rakyat sekitar \\
\hline
\end{tabular}

\section{SIMPULAN DAN SARAN}

\section{Simpulan}

Ganti rugi tanah karena uang kompensasi sangat menentukan terjadi gejolak atau tidak, perusahaan pengelola pertambangan harus mengadakan negosiasi dengan matang dan fair, disaksikan oleh pemda dll. Bahwa harga tanah yang dibayarkan benar-benar sesuai dengan kesepakatan antara perusahaan dan pemilik tanah, serta sesuai dengan ketentuan Pemda Kabupaten Kutai Barat. Pemda telah menetapkan nilai minimum dari tanah yang akan menjadi areal pertambangan. Kesepakatan harga kompensasi harus terbuka, adil, dan disaksikan oleh aparat pemda (camat, kepala desa). Dengan demikian, di belakang hari tidak ada lagi yang mempunyai alasan untuk berkelit atau mengingkari kesepakatan itu. 
Dalam masalah pencemaran lingkungan, perusahaan harus memperhatikan analisa dampak lingkungan (Amdal). Pencemaran lingkungan akan berdampak kepada penduduk baik di lokasi penambangan maupun di luarnya. Pencemaran lumpur, debu, bising, jalan rusak harus dihindarkan. Kolam pengolahan limbah harus diperhatikan dan perlu dipertontonkan bahwa air yang keluar dari lokasi sudah dijernihkan. Protes dengan tema pencemaran lingkungan hidup bisa mendapat dukungan rakyat banyak, bahkan bisa menarik perhatian dunia. Perusahaan harus memperhatikan adat. Kalau ada lokasi yang termasuk tanah adat, makam, dan lain-lain, lebih baik dihindarkan. Kalau toh dikalkulasi menguntungkan secara komersial dan sosial, boleh mengambilnya dengan kompensasi yang mahal dan diselesaikan dengan baik-baik. Konflik berdasarkan adat akan mendapat dukungan luas, dan akan menyulitkan posisi perusahaan maupun pengamanannya.

Pungutan resmi memang harus dipenuhi, karena pemerintah daerah memiliki otoritas untuk mengutip pungutan resmi. Kalau terjadi penggelapan atas pungutan resmi itu, perusahaan akan mendapat kesulitan dalam operasional perusahaan. Begitu perusahaan ketahuan melakukan penggelapan pajak, royalti atau kutipan lain, ia akan mendapat kesulitan dalam melakukan operasi. Sementara itu, premanisme ada dimana-mana. Mereka memiliki kepentingan sederhana yakni uang. Kalau perusahaan bisa mengakomodir mereka dengan uang atau pekerjaan, kemungkinan kelompok preman itu tidak mengganggu, Kalau perusahaan bisa memilih kelompok preman yang berpengaruh untuk pengamanan, kemungkinan bisa menyingkirkan preman-preman lain yang akan datang untuk memeras. Perusahaan juga mempekerjakan tenaga lokal, namun sering timbul masalah karena ratarata mereka kurang disiplin. Perusahaan diharapkan bisa melatih mereka, bukan hanya latihan skill, tapi juga pelatihan tingkah laku dan pola berpikir. Kalau tingkah lakunya sudah baik, tinggal ditingkatkan produktivitasnya dengan disiplin dan ethos kerja yang baik. Perusahaan hanya membagi duit kepada pemilik tanah. Tapi kehadiran perusahaan tidak disambut oleh masyarakat lain. Maka, perusahaan harus membuat CSR yang bisa dinikmati oleh masyarakat lebih luas di sekitar areal pertambangan seperti kesehatan, beasiswa, pendidikan, pemberdayaan ekonomi rakyat, aksi sosial, dan lain-lain. CSR yang benar dan berkesinambungan adalah yang mampu memberdayakan rakyat, bukan bersifat donasi karitatif.

Bagian external relation perusahaan harus rajin menjalin hubungan dengan LSM dan kelompok penekan lainnya, termasuk media massa. Hubungan baik itu akan mengendorkan niat LSM atau kelompok penekan untuk memprovokasi gerakan anti perusahaan. Perusahaan harus mencari kegiatan bersaman dengan LSM dan kelompok penekan itu agar bisa hidup berdampingan dan tidak saling curiga. Secara formal memang polisi yang layak dimintai bantuan kalau ada gangguan keamanan. Namun, sistem pengamanan internal sangat layak disiapkan untuk antisipasi kalau terjadi apa-apa dengan kegiatan pertambangan itu. Pengamanan dimaksud tentu bukan sekadar berupa pencurian atau pengrusakan peralatan, tapi bagaimana petugas pengamanan itu mampu meredakan dan negosiasi apabila terjadi unjukrasa dari warga. Kekerasan tidak bisa menyelesaikan gelombang massa yang datang. Setelah masa pinjam selesai atau setelah proses penggalian pertambangan selesai, perusahaan akan mengembalikan tanah kepada pemiliknya. Untuk membuat pemilik tanah tidak melancarkan protes karena ganti rugi, dll, maka perusahaan layak mengambil prakarsa menanami tanaman produktif (karet, buah, dll) di atas tanah yang digali dan sudah ditimbun lagi. Selain itu, perusahaan juga perlu mengambil hati pemilik tanah dengan persiapan pelatihan ketrampilan mengelola kebon karet, kolam ikan, dan lain-lain. Ada biaya, tapi komitmen itu akan meredam berbagai protes yang bisa diletuskan kapan saja.

\section{Saran}

Pemda setempat hendaknya menyediakan infrastruktur dan fasilitas lain seperti kesehatan, pendidikan, dll, yang memadai bagi segenap rakyat, baik yang memiliki tanah untuk areal pertambangan ataupun rakyat lain yang berada di sekitar pertambangan. Infrastruktur dan fasilitas tersebut bisa dibiayai dengan pendapatan daerah dari sektor pertambangan batubara. Dengan adanya 
fasilitas tersebut, siapa pun rakyat di Kutai Barat akan merasakan bahwa kehadiran pertambangan batubara sungguh memberikan manfaat bagi rakyat.

Perusahaan pengelola pertambangan batubara di wilayah kabupaten itu harus menyediakan dana memadai untuk kegiatan CSR (corporate sosial responsibility). Selain dana, perusahaan juga harus menunjukkan bahwa program CSR yang mereka lakukan demi menjalin hubungan baik dengan segenap stakeholder atau rakyat di sekitarnya. Program, CSR yang dilakukan oleh perusahaan bukan sekadar memberikan donasi karitatif, tapi terutama memberikan bantuan untuk pemberdayaan ekonomi rakyat, baik yang terlibat langsung dengan kegiatan pertambangan batubara maupun rakyat yang menjadi penonton di sekitar areal pertambangan. CSR harus disediakan secara berkelanjutan sehingga memberikan manfaat bagi rakyat dan segenap stakeholders dari perusahaan itu.CSR harus disediakan oleh perusahaan dengan mengacu dan memadukan 4 teori CSR yakni instrumental, political, integrative dan ethical theories.

Perusahaan juga mesti memahami dan senantiasa memperhatikan aspek kebudayaan, utamanya yang berkaitan dengan adat dan agama. Mereka, sebagian besar adalah suku Dayak Benuaq, yang memiliki pengaruh cukup besar dalam hal mindset, sikap, perilaku, dan respon mereka dalam interaksi sosial. Kendati adat tidak menentukan dan mempengaruhi urusan bisnis pertambangan batubara itu, tapi pengaruh terhadap perilaku, sikap dan pola pikir rakyat sangat besar. Baik perusahaan maupun Pemerintah Daerah jangan sampai menyimpan 'api dalam sekam' dalam kegiatan pertambangan batubara tersebut. Berbagai masalah yang potensial akan menggangu proses atau kegiatan pertambangan batubara, harus diselesaikan dari awal. Misalnya soal penyelesaian ganti rugi (kompensasi atas tanah), pengolahan limbah, rehabilitasi lahan bekas pertambangan, dan lain-lain. Walaupun penelitian dilakukan di Kutai Barat, secara umum pemetaan sosial tersebut juga bisa terjadi di berbagai areal pertambangan batubara di daerah lain. Namun, perlu diklarifikasi dan diidentifikasi lebih rinci masalah-masalah atau kandungan lokal di temat lain. Karena penelitian ini hanya berfokus pada social mapping dalam rangka CSR untuk mengantisipasi potensi konflik, utamanya di Kabupaten Kutai Barat, yang cakupannya sangat terbatas, maka disarankan agar dilakukan penelitian lanjutan yang lebih mampu menangkap masalah yang mungkin timbul dalam hubungan sosial (interaksi sosial) antara pemerintah daerah, perusahaan pertambangan dan rakyat Kutai Barat, khususnya yang berada di lokasi dan sekitar pertambangan.

\section{DAFTAR PUSTAKA}

Bowen, H. R. (1953). Social Responsibilities of the Businessman. New York: Harper and Row.

Gariga, E. \& Mele, D. (2004). “The Corporate Social Responsibility Theories: Mapping the Theory”. Journal Business Ethics. 53 no. 1-3, pp. 57-71.

Helmer, E. \& Stahl, K. (2009). How to define Corporate Social Responsibility. Jönköping University.

Spencer, B. \& Butler, J. K. (1987). "Measuring the Relative Importances of Social Responsibility Components: A Decision Modelling Approach”. Journal of Business Ethics 6. pp. 573-577.

Suharto, E. (1971). Metode dan Teknik Pemetaan Sosial (makalah). Bandung. 